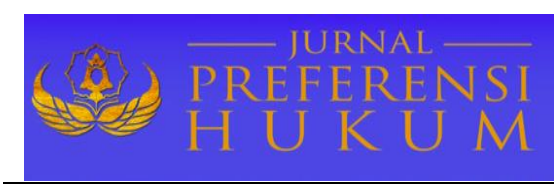

Jurnal Preferensi Hukum | ISSN: 2746-5039

Vol. 2, No. 1 -Februari 2021, Hal. 39-44| Available online at https://www.ejournal.warmadewa.ac.id/index.php/juprehum

DOI: https://doi.org/10.22225/jph.2.1.3049.39-44

\title{
PERLINDUNGAN HUKUM TERHADAP PEMEGANG DESAIN INDUSTRI YANG SAMA DENGAN MEREK YANG BERBEDA
}

\author{
Ni Komang Monica Dewi Maheswari, I Nyoman Putu Budiartha, Ni Madepuspasutari Ujianti \\ Fakultas Hukum Universitas Warmadewa Denpasar-Bali, Indonesia
}

\begin{abstract}
Abstrak
Desain industri dan merek yang telah terdaftar tidak dapat ditiru, dijiplak, dijual, atau disewakan tanpa sepengetahuan pemilik desain dan merek tersebut. Hak Desain industri dan merek perlu dilindungi demi terciptanya kondisi dunia bisnis yang aman, damai, dan adil. Hak kekayaaan intelektual tentunya memiliki peran penting dalam melindungi penciptanya dan karyanya agar tidak terjadi perilaku curang yang dilakukan orang lain, serta hak kekayaan intelektual memiliki hubungan yang sangat erat dengan Ilmu Pengetahuan dalam bidang Teknologi maupun Ekonomi. Hal ini dikarenakan hak kekayaan intelektual adalah hak yang lahir dari hasil daya pikir dan kreatifitas manusia yang dituangkan dalam berbagai macam kreasi yang mempunyai manfaat yang sangat berguna dalam kehidupan manusia dan juga memberikan keuntungan bagi sang pemiliknya. Penelitian ini bertujuan untuk menjelaskan ketentuan yang mengatur mengenai desain industri di Indonesia dan mendeskripskan akibat hukum apabila terjadi pelanggaran terhadap desain industri. Penelitian ini didesain menggunakan peneltian hukum normatif dengan menggunakan pendektan perundang-undangan. Adapun sumber data yang digunakan adalah data primer dan sekunder. Data diperoleh melalui dokumentasi, yaitu dengan cara membaca, merangkum serta meringkas bahan yang berkenaan dengan masalah yang sedang dteliti. Hasil penelitian menunjukkan bahwa Hukum memberikan perlindungan kepada sang pemegang hak dalam bentuk pencegahan para pelaku usaha curang yang membuat, memakai, menjual, mengekspor, mengimpor, atau mengedarkan barang yang diproduksi, tanpa sepengetahuan atau seizin dari sang pemilik hak desain tersebut. Kedua, jika ada orang maupun perusahaan yang bertindak curang terhadap hak desain industri, maka dapat diberikan sanksi administratif maupun sanksi pidana penjara dan ganti rugi.
\end{abstract}

Kata kunci: Desain industri, Merek, Perlindungan Hukum.

\begin{abstract}
Industrial designs and registered trademarks cannot be copied, copied, sold, or rented without the knowledge of the owners of the designs and marks. Industrial design rights and brands need to be protected in order to create a business world that is safe, peaceful and just. Intellectual property rights certainly have an important role in protecting their creators and their works so that there is no fraudulent behavior by others, and intellectual property rights have a very close relationship with science in the fields of technology and economics. This is because intellectual property rights are rights that are born from the results of human thinking and creativity which are manifested in various kinds of creations that have very useful benefits in human life and also provide benefits for the owner. This study aims to explain the provisions governing industrial design in Indonesia and describe the legal consequences if there is a violation of industrial design. This research was designed using normative legal research using statutory perspective. The data sources used were primary and secondary data. Data obtained through documentation, namely by reading, summarizing and summarizing the material with respect to the problem being studied. The results showed that the law provides protection to rights holders in the form of preventing fraudulent business actors from making, using, selling, exporting, importing, or distributing goods that are produced without the knowledge or permission of the owner of the design rights. Second, if there are people or companies that act fraudulently against industrial design rights, they can be given administrative sanctions as well as imprisonment and compensation.
\end{abstract}

Keywords: Industrial Design, Brand, Legal Protection.

\section{PENDAHULUAN}

Perdagangan bebas yang sedang berkembang saat ini, kemajuan sektor perdagangan sangat erat kaitannya dalam bidang ekonomi. Indonesia dalam dunia ekonominya dapat dikatakan sebagai Negara industri. Dengan persaingan di dunia bisnis, pelaku-pelaku usaha berusaha untuk terus memperbaharui produk dan terus melakukan inovasi terhadap produk yang diciptakan untuk memberikan hasil yang terbaik bagi konsumen (Chadhiq, 2007). Semakin banyak lahirnya para pelaku bisnis, maka semakin ketat juga persaingan diantara pelaku usaha tersebut, sehingga sangat diharapkan terjadinya pembangunan dunia ekonomi yang menjamin terwujudnya rakyat yang 
sejahtera (Wafiya, 2015). Upaya untuk meningkatkan daya saing dalam sektor industri dapat dilakukan dengan melakukan peningkatan dalam produktivitas industri dalam Negeri. Hak kekayaan intelektual banyak mengalami berbagai permasalahan atau sengketa antara lain, memakai atau mendaftarkan desain industri yang sama seperti desain orang lain dan menjiplak karya orang lain sehingga membuat sesuatu yang menghasilkan keuntungan dengan cara apapun bahkan melanggar hukum demi menguntungkan diri sendiri (Sulasno, 2019)

Hak kekayaaan intelektual tentunya memiliki peran penting dalam untuk melindungi penciptanya dan karyanya agar tidak terjadi perilaku curang yang dilakukan orang lain, serta hak kekayaan intelektual memiliki hubungan yang sangat dekat dengan Ilmu Pengetahuan termasuk bidang Teknologi maupun Ekonomi. Hal ini disebabkan karena HKI adalah hak yang lahir dari kemampuan daya pikir dan kreatifitas manusia yang dituangkan dalam berbagai macam kreasi yang mempunyai manfaat yang sangat berguna dalam kehidupan manusia dan juga memberikan keuntungan bagi sang pemiliknya. Dalam bidang kekayaan intelektual tersebut, terdapat bidang yang berkaitan dengan ilmu pengetahuan dan diterapkan dalam dunia industri, yaitu Hak Desain Industri.

Hak desain industri yang menjadi salah satu bagian dari HKI penting untuk dilindungi dan diapresiasi demi mencegah terjadinya Plagiarisme. Plagiarisme merupakan tindakan penjiplakan yang melanggar Hak Cipta yang membuat hasil karya tersebut seolah-olah merupakan hasil karyanya sendiri. Hak kekayaan intelektual banyak mengalami permasalahan atau sengketa seperti, menggunakan desain industri yang sama seperti desain orang lain dan menjiplak karya orang lain tanpa izin sehingga melanggar hukum demi menguntungkan diri sendiri. Persaingan usaha yang sehat adalah persaingan yang memperhatikan hak kekayaan intelektual pelaku usaha lainnya yang dapat dilakukan dengan cara meningkatkan kreatifitas produksi dan terus memperbaharui produk barang ataupun jasa sehingga dapat menarik perhatian konsumen dan bersaing dengan sehat dengan pelaku usaha lainnya.

Dalam dunia bisnis, ketatnya persaingan usaha tentunya tidak dapat dihindarkan, sehingga tingkat terjadinya perilaku pengusaha yang menyimpang sulit dipungkiri, dengan demikian semakin meningkat perindustrian di Indonesia maka semakin banyakpelanggaran yang muncul di dalamnya. Setiap perusahaan yang menciptakan produk dengan desainnya masing-masing, tentunya memiliki merek tersendiri pula yang dirancang sedemikian rupa yang berfungsi sebagai daya pembeda antara perusahaan satu dengan yang lainnya tentunya merek yang telah didaftarkan haknya, sehingga tidak dapat ditiru atau digunakan oleh yang bukan pemiliknya.

Merek dengan desain industri telah memiliki dasar peraturan yang berbeda. Merek diatur dalam UU Nomor 20 Tahun 2016 tentang merek dan indikasi geografis dan desain industri diatur dalam UU Nomor 31 Tahun 2000 tentang desain industri. Didalam ketentuan tentang merek dan desain industri tersebut telah diatur mengenai perlindungan suatu produk, prosedur pendaftaran, pengalihan hak dan lisensi, penyelesaian sengketa, serta ketentuan lainnya, namun tidak ditemukan pengaturan mengenai cara mengimplementasikan desain industri yang sama terhadap produk dengan merek berbeda. Undang-undang yang mengatur tentang merek dan desain Industri tidak memuat secara jelas bagaimana ketentuan bila antara pelaku usaha melakukan kolaborasi terhadap produk yang sama namun dengan merek berbeda.

Peneletian terdahulu yang relevan dengan peneltian ini mengungkapkan bahwa Perlindungan hak atas merek telah diatur sedemikian rupa untuk mendapatkan kepastian hukum (Semaun, 2016). Perlindungan hukum hak Desain Industri dalam Undang-Undang Nomor 31 Tahun 2000 tentang Desain Industri supaya Jangan sampai produk yang sudah beredar mudah ditiru dan didaftarkan oleh orang lain (Mokoginta, 2017). Penelitian lain Nadeak \& Wauran, (2019) Dalam pembuatan merek harus memiliki 1]kode tersendirir sesperti desain tiga dimensi dan desain industri, aspek yang dilihat adalah bentuk umum, bentuk yang tidak boleh didaftarkan, persepsi publik, kekhasan akibat penggunaan dan perluasan cakupan suatu tanda untuk dapat dijadikan merek.

Pemalsuan terhadap merek di Indonesia semakin meningkat, walaupun perlindungan hukumnya sudah diatur secara jelas dalam undang-undang, namun masih saja yanga melanggar demi mendapatkan keuntungan lebih banyak, oleh sebab itu Penelitian ini bertujuan untuk menjelaskan ketentuan yang mengatur mengenai desain industri di Indonesia dan mendeskripskan akibat hukum apabila terjadi pelanggaran terhadap desain industri. 


\section{METODE PENELITIAN}

Penelitian ini menggunakan metode penelitian hukum normatif, yang berdasarkan atas studi dokumentasi, yaitu dengan cara membaca, merangkum serta meringkas bahan yang berkenaan dengan materi yang dibahas. Penelitian normatif merupakan penelitian yang ditujukan pada peraturan tertulis atau bahan hukum lain (Achmad, 2013). Sumber bahan hukum yaitu bahan hukum primer meliputi bahan hukum yang bersumber dari peraturan perundang-undangan yang berhubungan dengan inti permasalahan yang diteliti, bahan hukum sekunder adalah bahan hukum yang memberikan penjelasan terhadap bahan hukum primer, seperti buku, artikel, dan lainnya yang dapat mendukung bahan hukum primer (Marzuki, 2005). Setelah diperoleh suatu bahan hukum dan telah dikumpulkan, kemudian diolah dan di analisis, dengan intrepretatif dan argumentatif, dimana bahan-bahan hukum akan dikaji dan dirangkai secara sitematis, penafsiran dan diberikan argumentasi untuk mendapatkan suatu simpulan sebagai hasil akhir dari penelitian ini.

\section{HASIL DAN PEMBAHASAN}

\section{Perlindungan Hukum Terhadap Pemegang Desain Industri}

Dasar hukum perlindungan desain industri yaitu diatur dalam UU RI No 31 Tahun 2000 dan PP RI Nomor 1 Tahun 2005 tentang pelaksanaan UU RI Nomor 31 Tahun 2000. Berdasarkan pasal 1 ayat 5 UU No. 31 Tahun 2000 tentang desain industri, dapat disimpulkan hak atas desain industri merupakan hak yang khusus bagi pemiliknya yang diberikan oleh Negara. Artinya hak tersebut sebagai konsekuensi telah didaftarkannya desain industri tersebut. Hukum memberikan perlindungan kepada sang pemegang hak dalam bentuk pencegahan para pelaku usaha curang yang membuat, memakai, menjual, mengekspor dan mengimpor atau mengedarkan barang yang diproduksi tanpa sepengetahuan atau seijin dari sang pemilik hak desain industri tersebut.

Hak desain industri yaitu hak eksklusif yang diberikan Negara kepada pendesain terhadap hasil kreasinya untuk jangka waktu tertentu melaksanakan sendiri, ataupun memberikan persetujuannya kepada pihak lain untuk menjalankan hak tersebut. Perlindungan hukum terhadap pemegang desain sangat berpengaruh terhadap suatu keadilan, ketertiban, kepastian, dan kemanfaatan dan kedamaian bagi para pemegang hak tersebut. Desain Industri yang dapat dilindungi tidak boleh bertentangan dengan moral dan kesusilaan. Perlindungan terhadap desain industri akan diberikan oleh DJHKI dengan berbagai persyaratan yang harus dipenuhi hal ini tercantum dalam pasal 10 UU Desain Industri. Menurut Rivan, (2016) Desain Industri merupakan sebuah hasil karya seseorang yang berupa gambar, garis, warna, dan gabungan dari padanya yang berbentuk dua dimensi atau tiga dimensi yang dapat menghasilkan suatu produk dan dapat bermanfaat bagi penjual barang dan jasa. Dari pengertian tersebut, maka produk atau barang yang dihasilkan merupakan gabungan kreativitas dan teknikal dalam proses perancangan produk industri dengan tujuan dapat digunakan oleh manusia sebagai hasil produksi. Jika hak dari pendesain terlindungi, maka pendesain akan terus berinovasi untuk menciptakan hal-hal baru yang mendorong perkembangan dalam dunia bisnis.

Dalam UU desain industri ditegaskan bahwa hak desain industri yang telah diberikan negara kepada pendesain diberikan untuk jangka waktu tertentu yang dalam kurun waktu tersebut pendesain memiliki hak eksklusif untuk melaksanakan sendiri atau memberikan persetujuan kepada pihak lain untuk melaksanakan hak tersebut, tentunya desain tersebut adalah harus desain yang baru dan sebelumnya telah didaftarkan secara tertulis kepada DJHKI. Hak desain industri diperoleh karena pendaftaran, tentunya pendaftaran yang mutlak untuk diperoleh nya suatu hak desain industri tersebut, tanpa adanya pendaftaran tidak akan diperoleh hak desain industri dan tentunya juga tidak akan mendapat perlindungan. Setiap orang atau para pelaku usaha berhak untuk memperoleh perlindungan dari Negara, termasuk perlindungan terhadap hak desain industri. Perlindungan tersebut yang termasuk didalamnya perlindungan hak ekonomi maupun hak moral yang diberikan secara memadai oleh negara akan berpengaruh terhadap kreasi pendesain yang tentunya memberikan kontribusi ekonomi yang besar, baik itu untuk pendesain maupun bagi negara.

Sistem pendaftaran desain industri di Indonesia adalah sistem yang bersifat konstitutif dengan pengertian pemilik desain yang sah dan diakui yaitu pihak yang pertama kalinya mendaftarakn desain tersebut pada DJHKI. Dengan demikian, perlindungan atas suatu desain tersebut akan diperoleh jika telah diaftarkan. Pentingnya pendaftaran desain oleh pendesainnya yaitu untuk memudahkan pembuktian dan perlindungannya ketika ada yang ingin mengakui atau mengklaim desain yang telah diaftarkan. Perlindungan desain industri dilakukan untuk memdorong iklim industri yang sehat dan 
untuk mencegah tindakan-tindakan peniruan desain serta praktik-praktik persaingan tidak jujur. Perlindungan hukum hukum terhadap desain industri mencakup terhadap pemalsuan desain dan desain dalam perdagangan. Perlindungan ini juga merupakan salah satu bentuk penegakan hukum terhadap desain industri yang berupa berupa tindakan administratif yang merupakan pelengkap dari bentuk perlindungan secara pidana maupun secara perdata.

Merek diatur dalam UU nomor 20 Tahun 2016 tentang Merek dan Indikasi Geografis. Merk dagang (Trademark) digunakan oleh pebisnis untuk mengidentifikasikan sebuah produk atau layanan. Perlindungan hukum terhadap merek harus melalui pengajuan permohonan kepada DJHKI. Merek yang didaftarkan tidak semuanya dapat diterima, dimana merek tersebut didaftarkan atas dasar permohonan yang diajukan oleh pemohon yang tidak beritikad baik. Pemohon yang tidak beritikad baik tersebut adalah pemohon yang mendaftarkan mereknya secara tidak layak dan tidak jujur, ataupun adanya niat tersembunyi seperti meniru atau menjiplak merek terkenal yang akan menimbulkan persaingan tidak sehat sehingga dapat menyesatkan konsumen. Merek dapat di tolak jika merek yang didaftarkan sudah terdaftar terlebih dahulu oleh pihak lain, merek yang terkenal milik pidak lain, berkaitan dengan indikasi geografis yang sudah terkenal. Perlindungan terhadap hak Merek diberikan kepada pemilik merek yang sudah terdaftar.

Perlindungan ini dilakukan untuk mencegah terjadinya pelanggaran hak merek yang dilakukan oleh pihak yang tidak mempunyai hak terhadap suatu merek. Merek memiliki prinsip territorial, yaitu hak merek hanya berlaku dimana permohonan paten diajukan dan diberi. Bentuk dari perlindungan hak merek yaitu, pemerintah melarang bagi orang yang meniru atau menjiplak simbol atau bentuk dari merek yang telah terdaftar untuk digunakan dalam kegiatan perdagangan barang atau jasa. Pendaftaran merek yang dilandasi dengan itikad buruk tidak akan diterima atau tidak akan dilindungi serta yang bertentangan dengan peraturan perundang-undangan, dan tidak memiliki daya pembeda. Pendaftaran merek juga dapat ditolak oleh Direktorat Jenderal HKI jika merek yang diaftar memiliki persamaan baik secara keseluruhan ataupun sebagian dengan merek yang telah terdaftar dan menjadi milik pihak lain Merek dagang meliputi nama produk atau layanan, beserta logo, simbol, gambar yang menyertaiproduk atau layanan tersebut (Firmansyah, 2001). Pemakaian merek bermanfaat untuk Tanda pengenal sebagai bentuk pembeda hasil ciptaan yang dihasilkan seseorang atau beberapa orang secara bersama-sama atau badan hukum dengan produksi orang lain atau badan hukum lainnya.Dalam hal perlindungan merek, investor harus mengajukan permohonan merek di Indonesia yaitu kepada Direktorat Jenderal Hak Kekayaan Intelektual. Menurut Saidin, (2013) Jangka waktu perlindungan Hak Merek berlaku selama 10 tahun sejak Tanggal Penerimaan. Masa perlindungan Hak Merek dapat diperpanjang setiap 10 tahun secara terus menerus. Pemegang Hak Merek sudah dapat mengajukan permohonan perpanjangan merek dari sejak enam bulan sebelum berakhirnya masa perlindungan merek sampai dengan 6 bulan sesudah masa perlindungan berakhir. Dengan adanya perlindungan terhadap merek menunjukkan bahwa Negara berkewajiban dalam menegakkan hukum merek. Dengan demikian apabila terjadi sengketa atau pelanggaran merek, maka pemilik merek dapat mengajukan gugatan ke kantor Pengadilan.

\section{Akibat Hukum Terhadap Pelanggaran Desain Industri}

Salah satu bentuk persaingan dalam hal desain industri yaitu, suatu perusahaan mobil yang meniru atau menjiplak desain perusahaan lainya, tetapi tidak ada yang saling menggugat terhadap hal tersebut, sehingga tercipta desain yang hampir mirip pada produk dari kedua perusahaan tersebut. Perusahaan tersebut yakni PT.TOYOTA DAN PT.DAIHATSU yang mengeluarkan mobil yaitu Toyota Avanza dan Daihatsu Xenia yang memiliki kemiripan pada desainnya, sementara dalam UU Desain Industri dan Merek tidak mengizinkan untuk membuat, menjual, meniru, menjiplak suatu desain yang sama yang tentu telah dipatenkan oleh orang lain dan sudah memiliki sertifikat hak desain maupun merek. Berdasarkan hasil wawancara yang telah dilakukan kepada Susanti Arista Dewi, umur 28 tahun, yang bekerja sebagai Sales Counter PT. Astra Daihatsu yang beralamat di Jalan Bypass Ngurah Rai Sanur Denpasar Bali dan Kadek Dewi Marantika, umur 27 tahun, yang bekerja sebagai sales Counter PT.Toyota Denpasar yang beralamat di jalan Cokroaminoto Nomor 47 Denpasar Bali, didapatkan hasil yaitu, dimana PT. Daihatsu dan PT.Toyota masing-masing mengeluarkan produk mobil Avanza dan Xenia pertama kalinya pada tahun 2004 dengan desain yang sama baik luar maupun dalam mobil hingga mesinnya. Setelah dianalisis hasil wawancara yang telah dilakukan, Kedua perusahaan ini yakni Toyota dan Daihatsu terbukti tidak melakukan pelanggaran 
hak desain industri dan merek karena kedua perusahaan tersebut merupakan satu payung perusahaan yang melakukan kolaborasi pada desain mobil Avanza dan Xenia, Hak Desain dari mobil Toyota Avanza dan Daihatsu Xenia adalah milik perusahaan PT.Astra Internasional, akan terjadi pelanggaran jika ada perusahaan lain yang bukan dari anak perusahaan Astra Internasional menggunakan merek atau desain industri seperti Toyota Avanza dan Daihatsu Xenia.

Setiap orang maupun perusahaan yang telah melakukan pelanggaran terhadap hak desain industri maupun merek dapat dikenakan sanksi bagi setiap pelakunya. Pada pelanggaran hak desain industri dapat dikenakan sanksi yaitu berupa ketentuan pidana dan gugatan ganti rugi sesuai dengan undangundang desain industri pasal 54. Hak merek merupakan suatu hak kebendaan, oleh karena haknya bersifat kebendaan maka hak tersebut dapat dipertahankan oleh siapa saja. Di dalam Pasal 76 Undang-Undang Merek disebutkan ada dua macam bentuk dari tuntutan gugatan yakni berupa permintaan ganti rugi dan penghentian dari pemakaian suatu merek. Ganti rugi tersebut harus dapat dinilai dengan uang, dan ganti rugi immaterial yakni berupa ganti rugi yang disebabkan oleh pemakaian merek dengan tanpa hak sehingga yang berhak menderita kerugian secara moril.

Upaya pemilik merek untuk mencegah pemakaian mereknya oleh pihak lain merupakan hal yang sangat penting dan sepatutnya dilindungi oleh hukum. Berkaitan dengan perlindungan merek, perdagangan tidak akan berkembang jika merek tidak mendapat perlindungan hukum yang memadai di suatu Negara. Pembajakan atau pelanggaran-pelanggaran merek tentunya tidak hanya merugikan para pengusahanya saja sebagai pemilik atau pemegang hak atas merek tersebut tetapi juga bagi para konsumen.

\section{SIMPULAN DAN SARAN}

\section{Simpulan}

Bedasarkan hasil analisis data, dapat disimpulkan bahwa Perlindungan hukum terhadap desain industri dan merek dapat diperoleh melalui pendaftaran ke DJHKI, perlindungan Desain Industri yaitu diatur dalam UU Republik Indonesia Nomor 31 tahun 2000 tentang Desain Industri Hukum melarang bagi orang yang tidak berhak untuk memakai atau menggunakan hak desain industri dan hak merek tersebut dengan tidak bertanggung jawab atau tanpa izin dan persetujuan dari yang berhak atas hak tersebut. Perlindungan hukum terhadap pemegang desain sangat berpengaruh terhadap suatu keadilan, ketertiban, kepastian, dan kemanfaatan dan kedamaian bagi para pemegang hak tersebut. Desain Industri yang dapat dilindungi tidak boleh bertentangan dengan moral dan kesusilaan. Perlindungan terhadap desain industri akan diberikan oleh DJHKI dengan berbagai persyaratan yang harus dipenuhi hal ini tercantum dalam pasal 10 UU Desain Industri, yang kedua pelanggaran yang dilakukan orang lain yang tidak berhak dan tidak bertanggung jawab akan mendapatkan akibat hukum yaitu sanksi yang tegas dan jelas, baik sanksi perdata berupa ganti rugi, penghentian perbuatan pelangaran dan penyitaan barang hasil pelanggaran untuk dimusnahkan dan sanksi pidana penjara dan atau denda perampasan barang yang digunakan untuk melakukan kejahatan dan juga dapat dikenakan sanksiadministratif berupa pencabutan surat izin usaha perdagangan.

\section{Saran}

Saran yang diajukan dalam penelitian ini adalah Kepada pemerintah disarankan untuk melengkapi Undang-Undang yang mengatur tentang desain industri maupun merek mengenai kesamaan dankemiripan terhadap suatu produk yang dikeluarkan dengan perusahaan yangberbeda dan dengan merek yang berbeda, agar tidak terjadi kesalahpahamanbaik dari masyarakat maupun para pelaku usaha, selanjutnya Kepada para pelaku usaha disarankan untuk tetap mematuhi peraturan perundangundangan yang berlaku mengenai hak kekayaan intelektual terutama pada bidang desain industri dan merek, serta lebih teliti untuk melindungi dan menjaga setiap ciptaan yang diproduksi sehingga tercapai situasi dan kondisi dunia bisnis yang aman dan nyaman bagi produsen maupun konsumen dan juga dapat mensosialisasikan kepada masyarakat awam tentang produk sama yang dikeluarkan dengan merek yang berbeda agar tidak timbul kesalahpahaman terhadap masing-masing perusahaan.

\section{DAFTAR PUSTAKA}

Achmad, M. F. N. Y. (2013). Dualisme Penelitian Hukum Normatif dan Emperis, Pustaka Pelajar. Pustaka Pelajar.

Chadhiq, U. (2007). Memahami Perilaku Konsumen Untuk Memenangkan Persaingan Bisnis. AKSES: Jurnal 
Ekonomi Dan Bisnis, 2(3), 59-72.

Firmansyah, H. (2001). Perlindungan Hukum terhadap Merek (Panduan memahami dasar hukum penggunaan dan perlindungan merek). Pustaka Yustisia.

Marzuki, P. M. (2005). Penelitian Hukum. Prenada Media.

Mokoginta, Z. A. (2017). Perlindungan Hukum atas Desain Industri Berdasarkan Undang-Undang Nomor 31 Tahun 2000 tentang Desain Industri. Lex Crimen, 20(2), 98-104.

Nadeak, N. A., \& Wauran, I. (2019). Tumpang-Tindih Pengaturan Bentuk Tiga Dimensi dalam Undang-Undang Merek dan Undang-Undang Desain Industri. Jurnal Hukum Ius Quia Iustum, 26(1), 21-43.

Rivan, S. S. (2016). Penerapan Penjatuhan Sanksi Pidana Terhadap Pelaku Pencurian Dokumen Elektronik Milik Orang Lain di Kota Makassar. Jurbal Hukum, 1(1), 80-103.

Saidin. (2013). Aspek Hukum Hak Kekayaan Intelektual. Rajawali Pers.

Semaun, S. (2016). Perlindungan Hukum terhadap Merek Perdagangan Barang dan Jasa. Journal of Chemical Information and Modeling, 14(1), 107-123.

Sulasno. (2019). Lisensi Hak Kekayaan Intelektual (Hki) dalam Perspektif Hukum Perjanjian di Indonesia. Jurnal Hukum, 3(2), 352-379.

Wafiya, W. (2015). Politik Hukum Pembentukan Undang-Undanglarangan Praktek Monopoli dan Persaingan Usaha Tidak Sehat. Jurnal Ilmu Hukum, 8(4), 657-680.

Undang-undang Nomor 20 tahun 2016 tentang Merek Lembar Negara Republik Indonesia Nomor 5953

Undang-undang Nomor 31 tahun 2000 tentang Desain Industri Lembaran Negara Republik Indonesia Tahun 2000 Nomor 243 